\title{
JAUNŲ DIRBANČIŲ ŽMONIŲ LAISVALAIKIO MOTYVACIJA
}

\section{Vilija Bitė Fominienè}

Lietuvos sporto universitetas

\begin{abstract}
ANOTACIJA
Straipsnyje nagrinėjama kokybiško laisvalaikio reikšmė dirbančio žmogaus sveikatai ir gyvenimo kokybės sampratai, pristatomi tyrimo duomenys, atskleidžiantys, kaip jauni dirbantys žmonès vertina savo sveikatą, ar turi pakankamai laisvalaikio, kokius pasirenka jo praleidimo būdus, veiklas. Pateikiami tyrimo rezultatai, išryškinantys pagrindinius motyvacinius veiksnius, lemiančius laisvalaikio pasirinkimą. Tyrimo rezultatai interpretuojami lyties ir tiriamujų savo sveikatos būklès vertinimo požiūriais.
\end{abstract}

Raktažodžiai: laisvalaikis, motyvacija, apsisprendimo motyvacijos teorija.

\section{IVADAS}

Sparti visų visuomenès gyvenimo sričių kaita lemia ne tik pažiūrų ir vertybių pokyčius, bet ir gamybos bei vartojimo didejjima, nustelbianti kitas gyvenimo sritis. Šiuolaikinès organizacijos, norėdamos išlikti konkurencingos, kaskart siūlo vis daugiau ir geresnès kokybès paslaugų bei produktų, pasitelkdamos tuos pačius, o neretai net mažesnius žmogiškuosius išteklius. Dèl šios priežasties neišvengiamai didèja darbuotojų darbo krūvis, o tai lemia nuolatini skubėjimą, nepastovią darbo aplinka, didèja psichoemocinè ittampa, neužtikrinama darbo sauga, ribojama sprendimų prièmimo laisvè. Vis daugiau dirbančių žmonių skundžiasi nugaros, kaklo ir pečių raumenų skausmais, patiria psichoemocinių sutrikimu, išgyvena stresa, depresija, nerimą (Ustinavičienė ir kt., 2004), o neretai teigia, kad darbas net kenkia jų sveikatai. Taigi dirbantieji ima prasčiau vertinti gyvenimo kokybę, nes jai turi itakos ne tik ekonominis žmonių aktyvumas, bet ir fizinė bei dvasinè sveikata, socialiniai ryšiai su aplinka, veiklos ir sprendimų laisvė, laisvalaikio prioritetai ir kiti veiksniai (Janušauskaitė, 2008; Savicka, 2006).

Tačiau žmogui darbas yra ir pragyvenimo šaltinis, ir pareiga. Vis dèlto, jeigu ši pareiga nualina jëgas, darbas gali tapti atgrasia našta. Kad taip neatsitiktų, kiekvienam dirbančiam žmogui reikalingas laisvas laikas - laisvalaikis, kad galètų atsipalaiduoti, pailsèti nuo varginančios kasdienès įtampos, atgauti darbinguma, ir pagerinti savo gyvenimo kokybę (Jurgelėnas ir kt., 2008). Tai ypač aktualu dirbantiems jauniems žmonėms. Ivairiose šalyse atlikti tyrimai rodo, kad jaunesni žmonès gyvenimo kokybę vertina geriau, rečiau skundžiasi savo sveikata, vis dèlto su metais šis vertinimas kinta (Kazlauskaitė, Rèklaitienè, 2005). Kaskart daugiau vyresnio amžiaus žmonių savo gyvenimo kokybę vertina prasčiau, todèl mažèja visos visuomenès fizinè, socialinè ir ekonominè galia, didèja socialinė rizika.

Taigi tampa ypač aktualu analizuoti tiek laisvalaikio ir jo naudos individui problemas, tiek veiksnius, galinčius užtikrinti veiksmingą laisvalaikio praleidimą.

Paprastai kiekviena žmogaus veikla yra motyvuota. Vadinasi, analizuojant veiksmingą laisvalaikị, kai žmogus atsipalaiduoja, atgauna jègas ir ugdosi, be laisvalaikio būdų ir pasirenkamų laisvalaikio veiklų, būtina žinoti ir veiksnius, lemiančius tų veiklų pasirinkimą. 
Šio tyrimo objektu pasirinkti laisvalaikio motyvacijos tipai. Tyrimo tikslas - ivertinti motyvacijos tipus, lemiančius jauno dirbančio žmogaus laisvalaikio motyvaciją.

\section{METODIKA}

Tyrimo metodai. Tyrimo tikslą geriausiai atitiko kiekybinis tyrimas, todèl darbe taikytas anketinès apklausos metodas. Tokia apklausa suteikia galimybę detaliau išanalizuoti jaunų dirbančių žmonių laisvalaikio veiklų pasirinkimo motyvacijos tipus.

Tyrimo imtis. Tyrime dalyvavo 70 jaunų žmonių, dirbančių Kauno mieste - 47 moterys (67 proc.) ir 23 vyrai (33 proc.). Respondentu amžius - nuo 18 iki 29 metų, 53 (77 proc.) tyrimo dalyviai buvo jaunesni nei 25 metų. Apklaustujų darbo stažas $-2,1 \pm 0,4$ metų.

Tyrimo organizavimas. Buvo taikomas kiekybinio tyrimo metodas - apklausa, naudojant pagal L. G. Pelettier ir kt. (1991) laisvalaikio motyvacijos skalę sudarytą 28 teiginių klausimyną. Klausimynas skirtas nustatyti individų laisvalaikio motyvaciją pagal septynis apsisprendimo motyvacijos tipus (vidinè motyvacija sužinoti, tobulèti, patirti, išorinė motyvacija identifikuoti poveiki, išorinė motyvacija perkelti poveiki, išorinis poveikis ir nemotyvuotumas). Klausimyno skalejje tiriamieji galejjo pasirinkti vieną iš septynių atsakymų variantų, rodančių motyvacijos veiksnių stiprumą. Atsakymų reikšmės: 1 - visiškai neatitinka, 2-3 - truputi atitinka, 4 - vidutiniškai atitinka, 5-6 - labai atitinka, 7 - visiškai atitinka.

Klausimyno teiginiai pagal apsisprendimo motyvacijos teoriją suskirstyti i septynis tipus:

1) 2, 9, 16, 23 teiginiai - vidinė motyvacija sužinoti,

2) 6, 13, 20, 27 teiginiai - vidinè motyvacija tobulèti,

3) 4, 11, 18, 25 teiginiai - vidinè motyvacija patirti,

4) 3,10,17, 24 teiginiai - išorinè motyvacija identifikuoti poveiki,

5) 7, 14, 21, 28 teiginiai - išorinè motyvacija perkelti poveiki,

6) $1,8,15,22$ teiginiai - išorinis poveikis,

7) 5, 12, 19, 26 teiginiai - nemotyvuotumas.

Tyrimas atliktas $2011 \mathrm{~m}$. vasario mènesi Kaune. Gauti duomenys apdoroti matematinès statistikos metodu.

\section{TYRIMO REZULTATAI IR APTARIMAS}

Didelę reikšmę asmens gyvenimo kokybei turi laisvalaikio turèjimas, jo praleidimo galimybės ir kokybė (Jurgelènas ir kt., 2008). Atlikus tyrimą nustatyta, kad didesnè respondentu dalis $(n=43$, 61 proc.) nurodė turintys nepakankamai laisvo laiko, mažiau respondentų $(n=25,36$ proc.) teige turintys pakankamai laisvo laiko, tačiau buvo ir respondentų ( $n=2,3$ proc.), teigusių, kad laisvo laiko jie praktiškai neturi. Išanalizavus turimo laisvo laiko pasiskirstymą per savaitę nustatyta, kad daugiausia laisvo laiko tiriamieji turi savaitgaliais $(n=47,67$ proc.), gana mažai jo turi šiokiadieniais $(\mathrm{n}=6,9$ proc.), tačiau dalis respondentų teigè pakankamai laisvo laiko turintys visada $(\mathrm{n}=17$, 24 proc.). 
Analizuojant tyrimo duomenis paaiškejjo, kad tiriamujų laisvalaikio veiklos yra skirtingos, o iš jų populiariausios - televizoriaus žiūrèjimas (12 proc.), sportavimas (11 proc.), dalyvavimas draugu vakarėliuose (11 proc.), sėdèjimas prie kompiuterio (10 proc.), pasivaikščiojimas (10 proc.). Iš šių duomenų matyti, kad tyrime dalyvavę jauni dirbantys žmonės laisvalaikio metu kiek dažniau renkasi pasyvias veiklas $(n=39,56$ proc.): žiūri televizorių, sėdi prie kompiuterio, skaito. Vis dèlto buvo nurodyta ir nemažai aktyvaus laisvalaikio praleidimo veiklų, pavyzdžiui, vaikščiojimas, bejgiojimas, važinėjimasis dviračiu, boulingo, krepšinio ir kt. žaidimas.

Norint paaiškinti, kodèl žmonès užsiima tam tikra veikla, tikslinga tirti jų motyvaciją. Motyvacijos teoriju yra daug ir ivvairių. Visos jos padeda atskleisti tam tikrus veiksnius, turinčius didžiausios ịtakos žmonių elgesiui įvairiose situacijose. Laisvalaikio motyvacijos suvokimui aiškinti gali būti sėkmingai naudojama Apsisprendimo motyvacijos teorija. Jos tikslas - paaiškinti individų motyvacija ir elgesi, atsižvelgiant i motyvacijos teorijų skirtumus, konteksto itaką ir tarpasmenini suvokimą (Hagger, Chatzisarantis, 2008; Walker, 2009).

Analizuojant, koki - aktyvų ar pasyvų - laisvalaiki renkasi Kauno mieste dirbantis jaunimas, buvo siekiama nustatyti tiriamujų motyvaciją pasirenkant tam tikrą laisvalaikio veiklą.

Išanalizavus tyrimo duomenis (1 pav.) nustatyta, kad jaunų dirbančių žmonių motyvaciją pasirenkant laisvalaikio veiklą daugiausia lemia vidinè motyvacija patirti (vidurkis - 5,7 balo). Vadinasi, pasirinkti tam tikras laisvalaikio veiklas labiausiai motyvuoja siekimas patirti, t. y. dauguma jaunų žmonių laisvalaikio veiklą renkasi siekdami patirti malonumą. O nemotyvuotumas mažiausiai lemia laisvalaikio veiklos pasirinkimą. Taigi abejingas požiūris ị laisvalaikio veiklą, t. y. veikimas dẻl veikimo, kai kuriems respondentams taip pat yra būdingas, tačiau nemotyvuotumas yra silpnesnis už išorinę bei vidinę motyvaciją rinktis kurią nors laisvalaikio praleidimo veiklą.

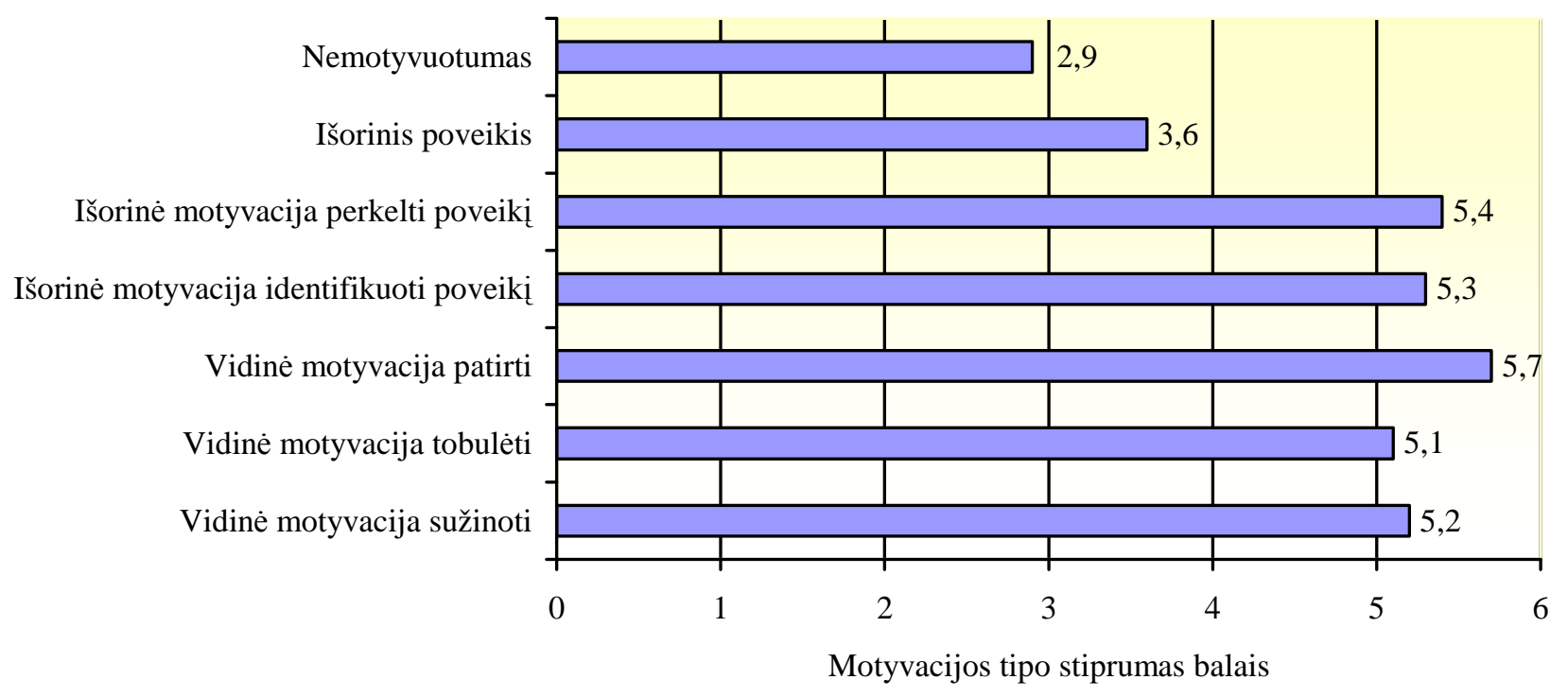

1 pav. Jaunimo laisvalaikio veiklos pasirinkimą lemiantys motyvacijos tipai 
Analizuojant laisvalaikio veiklos motyvaciją pagal lyti (2 pav.) nustatyta, kad renkantis laisvalaikio veiklą moterims daugiausia ittakos turi išorinis poveikis (motyvacijos tipo stiprumas 6,1 balo).

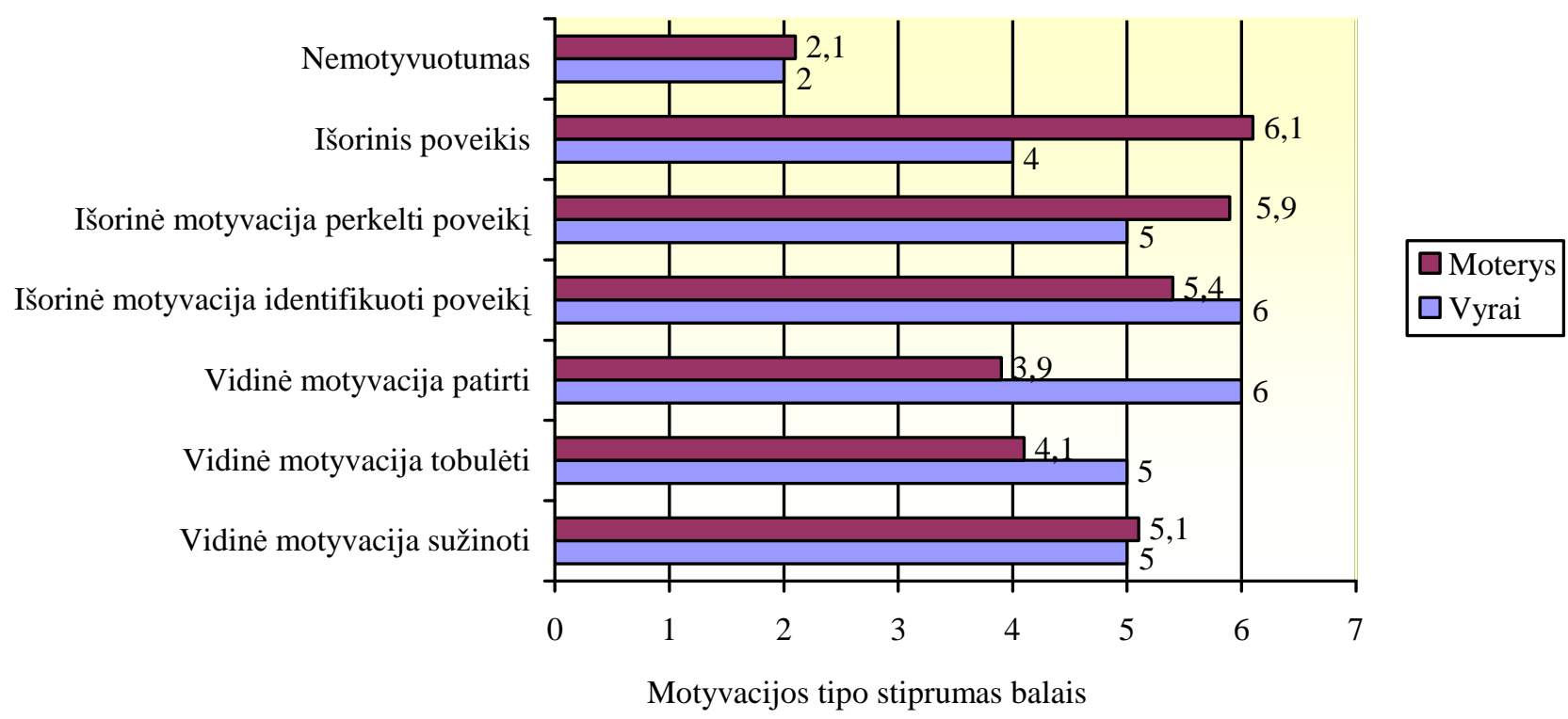

2 pav. Vyrų ir moterų laisvalaikio veiklos pasirinkimą lemiančių veiksnių skirstinys

Tyrimas parodè, kad moterys tam tikrą laisvalaikio veiklą dažniausiai renkasi dèl išorinio poveikio, pavyzdžiui, siekdamos gauti atlygi arba vengdamos bausmès. Veikdamos jos siekia, kad kiti dèl jų gerai jaustųsi ar kitiems dèl jų nebūtų gèda, taigi laisvalaikio veiklas renkasi ne dèl to, kad pačios to labai trokštu (Deci, Ryan, 2002). Daugiausia įtakos vyrams užsiimti tam tikromis laisvalaikio veiklomis turi tiek išoriné motyvacija identifikuoti poveiki, tiek vidinè motyvacija patirti (šių motyvacijos tipų stiprumas - 6 balai). Vadinasi, daugumai vyru pasirinkta laisvalaikio veikla turi teikti malonumą, nes tik taip stimuliuojamos tam tikros jų emocijos. Tokia veikla tampa jiems reikšminga, o veiklos rezultatai naudingi. Šioms respondentų grupėms, ypač vyrams, nemotyvuotumas yra mažiausiai būdingas. Taigi tikètina, kad pasirinkdami laisvalaikio veiklas vyrai turi daugiau interesų nei moterys.

Analizuojant, kaip jauni dirbantys žmonès vertina savo sveikatos būklę ir kokia jų laisvalaikio motyvacija, nustatyta, kad laisvalaikio veiklas respondentai pasirenka pagal suvokiamą savo sveikatos būklę. Pavyzdžiui, 70 proc. $(n=49)$ respondentų mano, kad jų sveikatos būklè yra gera, 23 proc. $(\mathrm{n}=16)$ - patenkinama, 4 proc. $(\mathrm{n}=3)$ - bloga, o 3 proc. $(\mathrm{n}=2)$ apklaustujų savo sveikatos būklès ivvertinti negalèjo. Analizuojant skirtingai savo sveikatos būklę vertinančių respondentų laisvalaikio motyvaciją buvo nustatyta, kad respondentai, kurie negalëjo ívertinti savo sveikatos būklès, yra labiausiai motyvuoti rinkdamiesi laisvalaikio veiklą (motyvacijos stiprumas - 6 balai). Šiai respondentų grupei renkantis laisvalaikio veiklą daugiausia ịtakos turi vidinė motyvacija sužinoti (3 pav.). Vadinasi, pasirinkta laisvalaikio veikla jiems teikia malonumą, suteikia galimybę siekti žinių, atrasti, tyrinėti, suprasti naujus dalykus. 


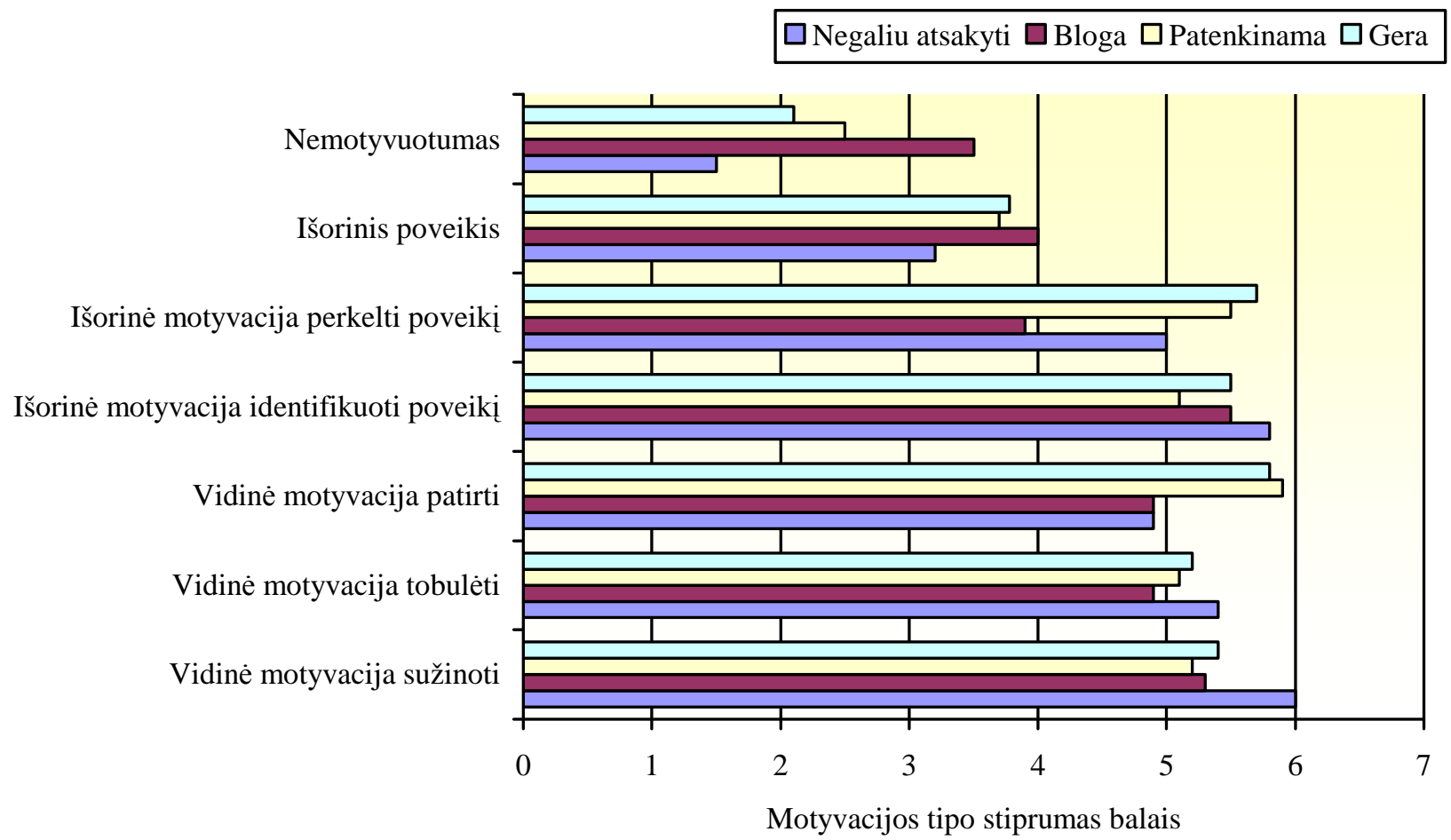

3 pav. Skirtingos sveikatos būklès respondentų laisvalaikio veiklos pasirinkimą lemiančių motyvacijos tipų skirstinys

Jauniems dirbantiems žmonėms, vertinantiems savo sveikatos būklę kaip gerą ir patenkinama, pasirenkant laisvalaikio veiklas daugiausia țtakos turi vidinè motyvacija patirti (vidurkis - 5,8 balo). Taigi šių grupių respondentams laisvalaikio veiklos sužadina emocijas, sukelia didžiuli vidini pasitenkinimą. O respondentams, savo sveikatos būklę suvokiantiems kaip blogą, daugiausia įtakos pasirenkant tam tikras laisvalaikio veiklas turi išorinè motyvacija identifikuoti poveiki (motyvacijos tipo stiprumas - 5,5 balo). Vadinasi, šios grupès respondentams laisvalaikio veiklos yra reikšmingos, o veiklų rezultatai yra arba turètų būti naudingi, vis dèlto jos neteikia vidinio pasitenkinimo. Tiriamiesiems, savo sveikatos būklę vertinantiems kaip blogą, būdingas didžiausias nemotyvuotumas, todèl galima teigti, kad jie yra gana apatiški rinkdamiesi laisvalaikio veiklas.

L. I. Caldwell ir kt. (2010) išskiria keletą priežasčių, dèl kurių jaunimas pasirenka tam tikras laisvalaikio veiklas. Pirma priežastis ta, kad motyvacija ne tik lemia tam tikrą elgesį, bet yra susijusi ir su įvairiomis jo pasekmėmis. Teoriškai tam tikri motyvacijos tipai, pavyzdžiui, vidinè motyvacija ar išorinè motyvacija identifikuoti poveikį, didina elgesio efektyvumą, stiprina priklausymo ir subjektyviai suvokiamos gerovès jausmą. Visi kiti išorinès motyvacijos tipai, taip pat ir nemotyvuotumas, siejami su silpnesniu subjektyviai suvokiamos gerovès jausmu. Kita priežastis ta, kad laisvalaikio ir laisvalaikio motyvacijos sąsaja yra labai glaudi - tai rodo asmens apsisprendimas ir vidinès motyvacijos skatinamas elgesys laisvalaikiu. Kitaip tariant, labiausiai asmens poreikius tenkina ta laisvalaikio veikla (ar veiklos), kuri pasirenkama tik tvirtai apsisprendus. 


\section{IŠVADOS}

1. Jaunų dirbančių žmonių laisvalaikio tyrimas parodè, kad tarp įvairių laisvalaikio praleidimo būdų kiek labiau vyrauja pasyvus laisvalaikis savaitgaliais.

2. Tiriant jaunimo laisvalaikio pasirinkimo motyvaciją nustatyta, kad pasirenkant laisvalaiki daugiausia įtakos turi vidiné motyvacija patirti, t. y. tiriamieji siekia vidinio pasitenkinimo, kad maloni veikla žadintų teigiamas emocijas. Analizuojant motyvacinių veiksnių stiprumą lyties požiūriu nustatyta, kad moterų laisvalaikio veiklą labiau skatina išorinis poveikis, o vyrų - išorinè motyvacija perkelti poveiki ir vidinè motyvacija sužinoti. Taigi pasirinkę tam tikrą laisvalaikio veiklą tiriamieji siekia išorinio atpildo arba vengia išorinès bausmès, siekia vidinio atpildo arba vengia vidinès bausmès, stengiasi igyti daugiau žinių, tyrinèti, suprasti.

3. Analizuojant, kaip jauni dirbantys žmonès suvokia savo sveikatos būklę ir kokia jų laisvalaikio veiklos motyvacija, nustatyta, kad asmenims, negalëjusiems ịvertinti savo sveikatos būklès, apatija renkantis laisvalaikio praleidimo formas yra nebūdinga ir jie yra gana tvirtai apsisprendę bei žino, ko siekia. Asmenys, manantys, kad jų sveikatos būklè bloga, laisvalaikio veiklas renkasi veikiami išorinès motyvacijos identifikuoti poveiki laisvalaikio veiklos jiems yra reikšmingos, o veiklų rezultatai yra arba bus naudingi, tačiau jie nejaučia vidinio pasitenkinimo.

\section{LITERATŪRA}

1. Caldwell, L. I., Patrick, M. E., Smith, A. E., Palen, L. A., Wegner, L. (2010). Influencing adolescent leisure motivation: intervention effects of health wise South Africa. Journal of Leisure Research, 42 (2), 203-220.

2. Deci, E. L., Ryan, R. M. (2002). Handbook of Self-Determination Research. Rochester: The University of Rochester Press.

3. Hagger, M., Chatzisarantis, N. (2008). Self-determination Theory and the psychology of exercise. International Review of Sport and Exercise Psychology, 1 (1), 79-103.

4. Janušauskaitè, G. (2008). Gyvenimo kokybès tyrimai: problemos ir galimybės. Filosofija. Sociologija, t. 19 (4), 34-44.

5. Jurgelėnas, A., Juozulynas, A., Butkienè, B., Butikis, M., Savičiūtè, R. (2008). Gyvenimo kokybės ir amžiaus integralumo bruožai. Gerontologija, 9 (4), 207-213.

6. Kazlauskaitè, M., Rèklaitienè, R. (2005). Vidutinio amžiaus Kauno gyventojų gyvenimo kokybè. Medicina (Kaunas), 41 (2), 155-161.

7. Pelletier, L. G., Vallerand, R. J., Blais, M. R., Brière, N. M. (1991). Leisure motivation scale. Internet link: http://www.er.uqam.ca/nobel/r26710/LRCS/scales/eml28_en.doc [retrieved: 2010-10-03].

8. Savicka, A. (2006). Darbas ir laisvalaikis: naujos jų tarpusavio ryšio sampratos paieškos. Kultūrologija, 13, 183- 204.

9. Ustinavičienė, R., Obelenis, V., Ereminas, D. (2004). Dirbančiujų sveikata ir šiuolaikinės darbo sallygos. Medicina (Kaunas), 40 (9), 897-904.

10. Walker, G. J. (2009). Culture, self-construal, and leisure motivations. Leisure Sciences, 31, 347-363. 


\title{
YOUNG WORKING PERSON'S LEISURE MOTIVATION
}

\section{Vilija Bitė Fominienè}

Lithuanian Sports University

\begin{abstract}
Theoretical substantiation. The article explores the recreational value and importance of working in human life, analysis of its association with human health and quality of life perception. Any human activity is motivated, so the analysis of effective leisure time, determined not only selected leisure activities, but also reveals the need for the factors, which determine the choice of such activities.
\end{abstract}

The object of the survey was the choice of motivational factors in leisure.

The aim of study was to assess the determining factors of leisure motivation of young working people

Method. Organized research through a questionnaire based on L. G. Pelletier et al. (1991) leisure motivation scale. The sample consisted of 70 young working people from Kaunas city - 47 women and 23 men. The study investigated whether young working people have enough leisure time, what are its forms and conducting research to evaluate the disclosure of their health. In determining what are the key motivating factors behind the choice of leisure study comparing interpretations of gender and health research aspects of perception. The study data were processed on the basis of mathematical statistics

Findings. The survey data suggests that young working people have more leisure time on weekends and often spends it passively (reading, watching television). Examination of the leisure motivation of the youth revealed that most strongly influenced by the choice of leisure internal motivation to experience stimulation, i. e., targeted to the inner satisfaction, enjoyable activities that stimulate feelings of certain associations. Youth groups, by gender dominated external motivation external regulation, external regulation motivation moved, the internal motivation to know, that is these groups of people belonging to an external reward or avoid an external punishment, reward or to avoid the inner interior penalty, to seek knowledge, explore, understand the relevant issues. The analysis of young people's perceptions of their health status and the motivation of leisure activities to those persons who are unable to assess their health status is at least apathetic choosing forms of leisure and are sufficiently strong and determined to knowing what is going. Those persons who believe that there is poor health status in the form of leisure for engaging external motivation identified regulation - they are important leisure activities, and results are or will be useful, but it does not feel the inner satisfaction.

Keywords: leisure, motivation, Self-determination Theory. 


\section{МОТИВАЦИЯ ДОСУГА МОЛОДЫХ РАБОТАЮЩИХ ЛЮДЕЙ}

\section{Вилия Бите Фоминене}

Литовский университет спорта

\section{РЕЗЮМЕ}

Теоретическое обоснование. В статье рассматриваются ценность и важность рекреации в жизни человека, анализируются её связи со здоровьем человека и восприятием качества жизни. Любая деятельность человека мотивирована. Таким образом, анализируя эффективность досуга, способного обеспечить восстановление сил молодого работающего человека, его саморазвития, нужно анализировать не только формы и виды рекреации, необходимо знать и факторы, определяющие выбор различных видов деятельности.

В этой работе объектом исследованиия являются мотивационные факторы выбора досуга.

Цель исследования - оценить мотивационные факторы выбора досуга молодого работающего человека.

Методика. Для достижения намеченной цели во время исследования было опрошено 70 людей, работающих в городе Каунасе (47 женщин и 23 мужчины). Исследование проведено согласно подготовленному опроснику по примеру Л. Г. Пеллетье и др. (1991). В опросник входят вопросы, позволяющие проанализировать, достаточно ли свободного времени имеют молодые трудящиеся, какие формы его проведения, выявить, как они оценивают свое здоровье. Изучив, какие основные мотивационные факторы влияют на выбор досуга, полученные результаты интерпретируются в зависимости от пола и восприятия состояния здоровья. Полученные с помощью опросника данные были обработаны по методу математической статистики.

Результаты. Исследование показало, что большинство респондентов не имеют достаточно свободного времени или его не имеют совсем. Молодые люди отметили, что в основном имеют свободное время только по выходным. В это время они занимаются различной деятельностью. Среди самых популярных занятий досуга являются просмотр телевизионных передач, вечеринки с друзьями, занятие спортом, время проведение за компьютером и чтение. Изучив мотивацию выбора досуга молодых людей установленно, что сильнее всего он зависит от внутренней мотивации - испытать, изведать. Это значит, что молодые люди ориентированы на внутреннее удовлетворение.

Выводы. Исследование показало, что у молодых работающих людей преобладает более пассивный досуг, особенно по выходным. Мотивация выбора досуга молодежи зависит от внутренней мотивации. Те лица, которые не могут оценить состояние своего здоровья, являются апатичными при выборе различных форм досуга, но достаточно твёрдо знают, чего хотят. Те люди, которые думают, что их состояние здоровья является плохим, в соответствующие формы досуга вовлечены благодоря внешней мотивации - деятельность досуга является важной, а полученный результат для них полезным, но это не позволяет получить внутреннее удовлетворение.

Ключевые слова: досуг, мотивация, самомотивационная теория. 